\title{
Penelitian Numerik Turbin Angin Darrieus dengan Variasi Jumlah Sudu dan Kecepatan Angin
}

\author{
Rahmat Taufiqurrahman dan Vivien Suphandani \\ Jurusan Teknik Mesin, Fakultas Teknologi Industri, Institut Teknologi Sepuluh Nopember (ITS) \\ Jl. Arief Rahman Hakim, Surabaya 60111 Indonesia \\ e-mail:vivien_s@me.its.ac.id
}

\begin{abstract}
Abstrak-Penelitian ini dilakukan agar didapatkan desain turbin angin terbaik yang mampu memanfaatkan tenaga angin seoptimal mungkin. Metode penelitian yang digunakan adalah penelitian numerik dua dimensi dengan analisis aliran unsteady menggunakan software STAR CCM+ 9.02.007-R8. Model turbin angin yang digunakan adalah turbin angin tipe Darrieus dengan profil airfoil sudu sesuai NACA 0024 dengan jumlah sudu 3 dan 4. Turbulence model yang digunakan adalah k-epsilon realizable. Metode meshing yang digunakan adalah automated mesh dengan tipe tetrahedral mesh. Kecepatan angin yang disimulasikan adalah sebesar 5, 7, 9, 11, 13, dan $15 \mathrm{~m} / \mathrm{s}$. Hasil yang diperoleh dari penelitian ini adalah visualisasi kontur kecepatan dan tekanan, serta data grafik berupa nilai torsi dan koefisien daya dari turbin angin Darrieus. Turbin angin Darrieus tiga sudu menghasilkan koefisien daya yang lebih tinggi daripada turbin angin Darrieus empat sudu dalam rentang TSR 1,08-1,28. Nilai koefisien daya tertinggi dari turbin angin Darrieus tiga sudu adalah 0,437 yang dicapai pada TSR 1,28. Namun turbin angin Darrieus empat sudu memiliki profil grafik torsi yang lebih stabil dibandingkan dengan turbin angin Darrieus tiga sudu.
\end{abstract}

Kata Kunci-Darrieus, Jumlah Sudu, Kecepatan Angin, Koefisien Daya, Metode Komputasi Fluida.

\section{PENDAHULUAN}

$\mathrm{T}$ URBIN angin Darrieus adalah turbin angin jenis vertical axis wind turbine (VAWT) yang memiliki efisiensi tinggi dan mampu menghasilkan torsi cukup besar pada putaran dan kecepatan angin yang tinggi. Penelitian kali ini dilakukan dengan memodelkan mini turbin angin Darrieus dengan profil airfoil simetris sesuai NACA 0024. Penelitian ini dilakukan dengan memvariasikan jumlah sudu turbin, yaitu 3 sudu dan 4 sudu, dan variasi kecepatan angin freestream sehingga didapatkan nilai torsi dan koefisien daya yang optimal.

Pada penelitian [1] telah dilakukan eksperimen dan penelitian numerik (2D) untuk mengetahui performa dan evaluasi aliran pada turbin angin Darrieus aliran rendah. Penelitian ini menghasilkan kesimpulan bahwa grafik koefisien daya vs TSR yang dihasilkan melalui penelitian numerik lebih tinggi daripada grafik yang dihasilkan oleh eksperimen karena metode penelitian numerik tidak mampu menangkap fenomena $3 \mathrm{D}$ yang terjadi pada turbin angin sesungguhnya.

Penelitian selanjutnya [2] dilakukan untuk mengetahui pengaruh jumlah sudu dan panjang chord sudu terhadap efisiensi turbin angin Darrieus tipe melintang dengan menggunakan metode numerik (2D) yang menghasilkan kesimpulan bahwa peningkatan koefisien torsi sebanding dengan peningkatan solidity untuk jumlah sudu $\leq 3$ dan hal sebaliknya terjadi untuk jumlah sudu $\geq 3$.

Pada penelitian [3] dilakukan eksperimen untuk mengetahui desain turbin angin Darrieus-Savonius yang optimum. Dari penelitian ini didapat hasil bahwa semakin besar kecepatan angin, maka energi yang dihasilkan pun semakin besar.

Penelitian [4] dilakukan untuk menganalisis hubungan antara aspect ratio pada turbin angin sumbu vertikal $\mathrm{H}$-rotor dengan performanya (koefisien daya). Penelitian ini menghasilkan kesimpulan bahwa turbin angin dengan aspect ratio yang rendah memiliki koefisien daya yang lebih tinggi

\section{METODOLOGI PENELITIAN}

Penelitian dilakukan dengan melalui tiga tahapan utama, yaitu tahap pre-processing, processing, dan post processing. Tahap pre-processing mencakup pembuatan geometri yang ditunjukkan pada gambar 1, meshing seperti pada gambar 2, penetapan boundary condition seperti yang ditampilkan pada gambar 3, dan penentuan parameter.

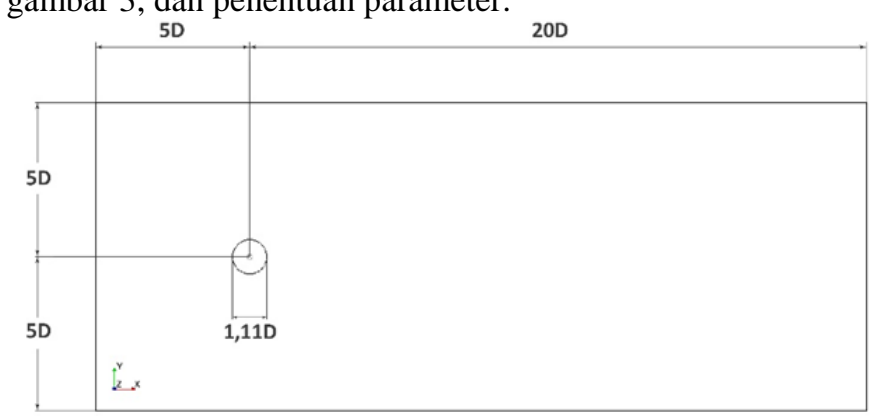

a

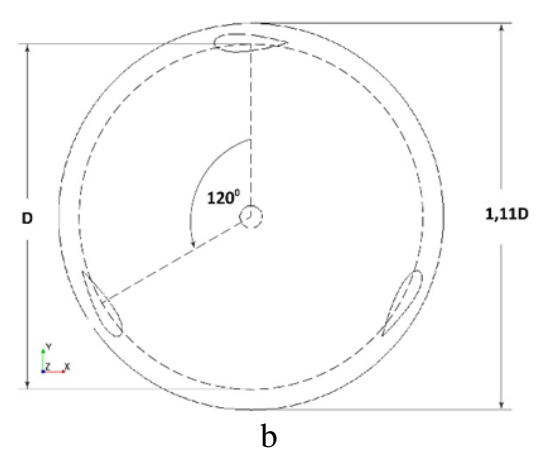

Gambar. 1. Dimensi domain turbin angin Darrieus tiga sudu. (a) Dimensi static domain. (b) Dimensi rotating domain.

Bentuk mesh yang digunakan adalah tetrahedral mesh dengan metode automated mesh dan dengan jumlah cell sebanyak 242.256. 


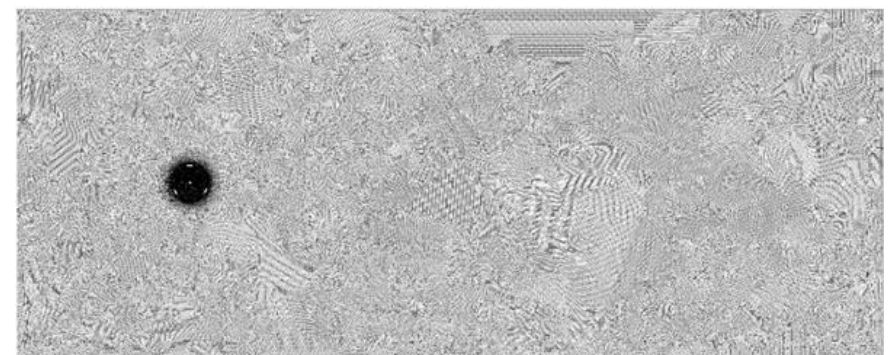

(a)

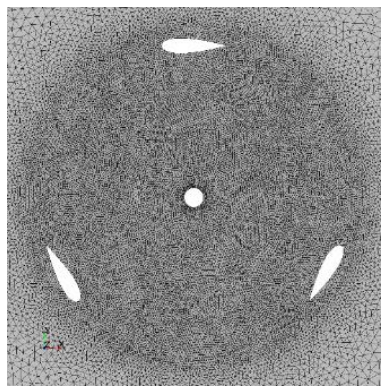

(b)

Gambar. 2. Mesh turbin angin Darrieus tiga sudu. (a) Mesh static domain. (b) Mesh rotating domain.

Boundary condition yang digunakan pada inlet adalah velocity inlet dengan nilai kecepatan freestream yang melaluinya yaitu $5,7,9,11,13$, dan $15 \mathrm{~m} / \mathrm{s}$, sedangkan pada outlet digunakan flow-split outlet, pada setiap sudu dan poros digunakan wall dengan rotation motion, batas atas dan bawah sebagai symmetry plane dan pada pertemuan antar dua domain didefinisikan sebagai interface.
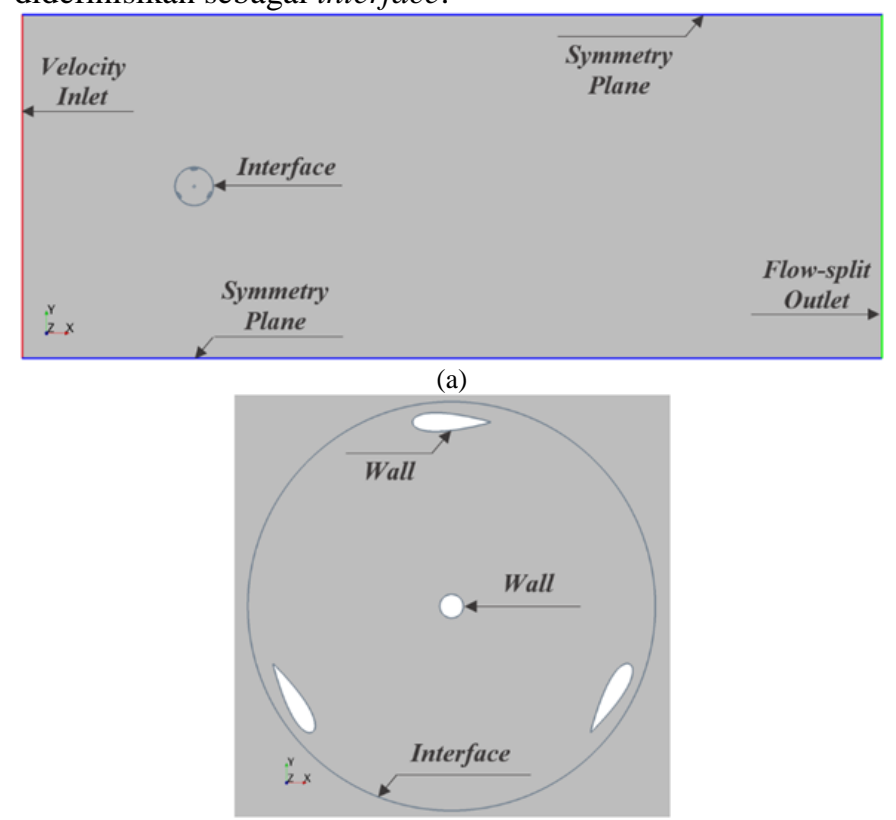

(b)

Gambar. 3. Boundary conditions turbin angin Darrieus tiga sudu. (a) Boundary condition static domain. (b) Boundary condition rotating domain.

Fluida kerja pada simulasi ini adalah udara dengan density $1,18415 \mathrm{~kg} / \mathrm{m}^{3}$ (constant) dengan dynamic viscosity $1,85508 \mathrm{E}-$ 5 Pa.s (constant). Kriteria konvergensi ditentukan pada 10E-5.

Putaran turbin pada kecepatan freestream $9 \mathrm{~m} / \mathrm{s}$ diadaptasi dari [3] dengan asumsi parameter lainnya sama kemudian mengekstrapolasikannya untuk kecepatan lainnya. Berdasarkan hasil perhitungan didapat nilai putaran turbin, tip speed ratio dan time step untuk setiap kecepatan freestream.

$$
\text { Tabel } 1 .
$$

Nilai putaran turbin dan TSR pada tiap kecepatan angin

\begin{tabular}{ccc}
\hline \hline $\begin{array}{c}\text { Kecepatan Angin } \\
(\mathrm{m} / \mathrm{s})\end{array}$ & $\begin{array}{c}\text { Putaran Turbin } \\
(\mathrm{rpm})\end{array}$ & Tip Speed Ratio \\
\hline 5 & 440 & 1,08 \\
7 & 666 & 1,17 \\
9 & 892 & 1,21 \\
11 & 1119 & 1,25 \\
13 & 1345 & 1,27 \\
15 & 1572 & 1,28 \\
\hline \hline
\end{tabular}

Tabel 2

Nilai time step pada tiap kecepatan angin

\begin{tabular}{cccccc}
\hline \hline $\begin{array}{c}\mathrm{v} \\
(\mathrm{m} / \mathrm{s})\end{array}$ & $\begin{array}{c}\omega \\
(\mathrm{rpm})\end{array}$ & $\begin{array}{c}\omega \\
(\mathrm{rad} / \mathrm{s})\end{array}$ & $\begin{array}{c}\text { Jumlah } \\
\text { Frame }\end{array}$ & $\begin{array}{c}\text { Waktu Per } \\
\text { Putaran }(\mathrm{s})\end{array}$ & $\begin{array}{c}\text { Time } \\
\text { Step }\end{array}$ \\
\hline 5 & 440 & 46,10 & & 0,13631 & 0,00189 \\
7 & 666 & 69,77 & & 0,09005 & 0,00125 \\
9 & 892 & 93,45 & 72 & 0,06724 & 0,00093 \\
11 & 1119 & 117,23 & & 0,05360 & 0,00074 \\
13 & 1345 & 140,90 & & 0,04459 & 0,00062 \\
15 & 1572 & 164,69 & & 0,03815 & 0,00053 \\
\hline \hline
\end{tabular}

Adapun geometri, mesh, boundary conditions, dan parameter yang digunakan pada turbin angin Darrieus empat sudu mengikuti spesifikasi yang digunakan pada turbin angin Darrieus tiga sudu.

\section{HASIL DAN DISKUSI}

\section{A. Kontur Kecepatan}

Gambar 4 menunjukkan kontur kecepatan turbin angin Darrieus tiga sudu pada berbagai sudut putar dengan kecepatan angin $15 \mathrm{~m} / \mathrm{s}$. Pada gambar 6 dan 7 dapat dilihat bahwa kecepatan putar tertinggi turbin angin terjadi saat kecepatan angin (freestream) $15 \mathrm{~m} / \mathrm{s}$ karena kenaikan kecepatan putar turbin berbanding lurus dengan pertambahan kecepatan angin yang melalui turbin angin. Pada gambar kontur kecepatan tersebut pertambahan sudut putar akan menambah nilai angle of attack dan mempengaruhi gaya lift yang terjadi. Ketika turbin angin mencapai sudut putar $90^{\circ}$, gaya lift yang terbentuk lebih besar daripada posisi sudut putar sebelumnya dikarenakan perbedaan tekanan antara sisi terluar dan sisi terdalam sudu yang tegak lurus aliran freestream menjadi lebih besar daripada sudu lainnya, seperti terlihat pada gambar 8 dan 9, sehingga memicu angin mengalir dari tekanan tinggi menuju tekanan rendah yang mengakibatkan turbin berputar dengan lebih baik. Semakin besar gaya lift maka semakin besar pula torsi yang dihasilkannya.

Pada sudut putar $90^{\circ}$ mulai muncul vortex yang menyebabkan penurunan gaya lift pada sudu sehingga kecepatannya pun menurun. Sudu turbin angin yang telah melalui sudut putar $90^{\circ}$ mengalami penurunan kecepatan hingga mencapai sudut putar $360^{\circ}$ dikarenakan adanya pengaruh dari vortex yang terbentuk dan kondisi kecepatan angin yang mengalir pada daerah downstream tidak secepat pada daerah upstream. Gambar 5 menunjukkan kontur kecepatan turbin angin Darrieus empat sudu pada berbagai sudut putar dengan kecepatan angin $15 \mathrm{~m} / \mathrm{s}$ dengan penjelasan fenomena yang sama dengan turbin tiga sudu, hanya saja turbin 
angin empat sudu memiliki lebih banyak sudu di daerah downstream dengan kecepatan rendah.

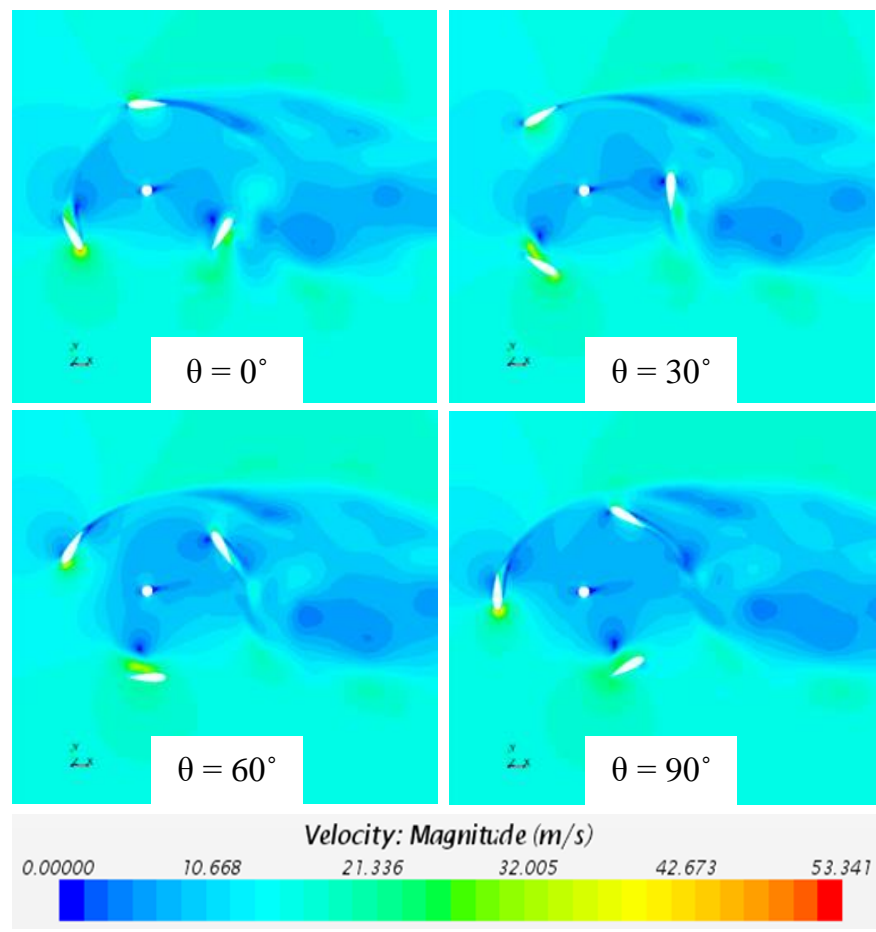

Gambar. 4. Kontur kecepatan turbin angin Darrieus tiga sudu pada berbagai sudut putar dengan kecepatan freestream $15 \mathrm{~m} / \mathrm{s}$.

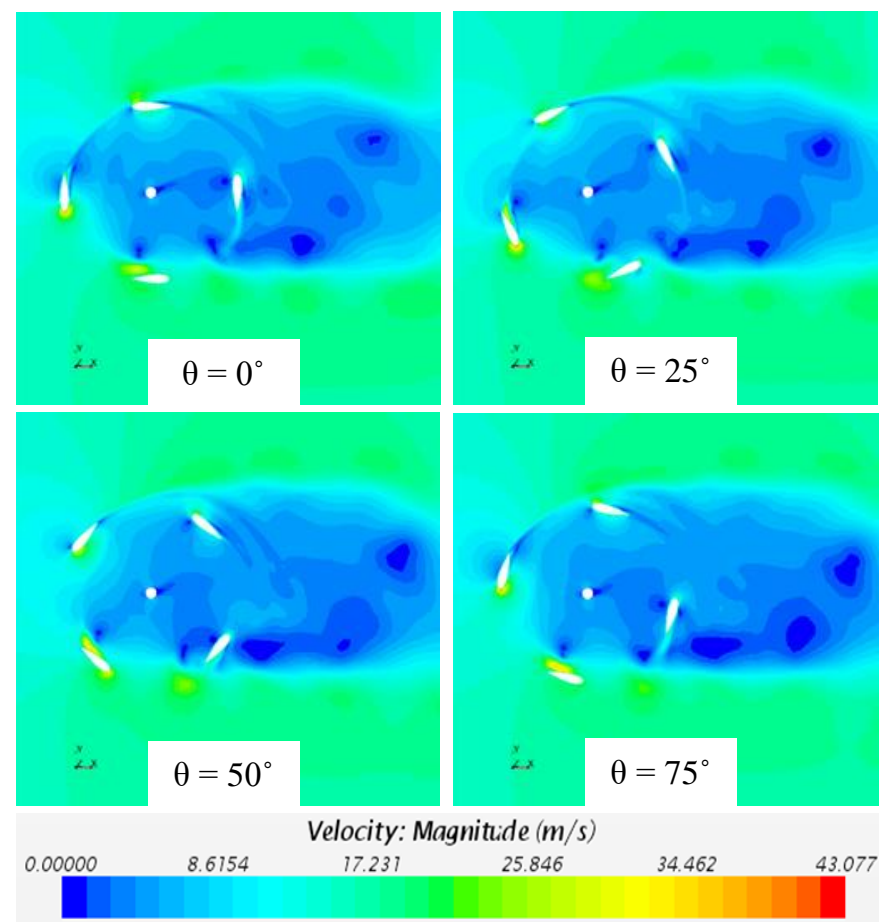

Gambar. 5. Kontur kecepatan turbin angin Darrieus empat sudu pada berbagai sudut putar dengan kecepatan freestream $15 \mathrm{~m} / \mathrm{s}$.

Turbin angin Darrieus empat sudu memiliki kemampuan menghasilkan gaya lift dan torsi yang lebih kecil daripada turbin angin Darrieus tiga sudu dikarenakan banyaknya sudu di daerah downstream yang menjadi penghambat sudu di daerah upstream. Oleh karena itu, kecepatan maksimum pada sudu turbin angin Darrieus empat sudu tidak setinggi kecepatan maksimum pada sudu turbin angin Darrieus tiga sudu, begitupun dengan koefisien daya yang dihasilkannya.

Pada daerah downstream ini pun terdapat kenaikan kecepatan dan vortex yang terjadi, baik pada turbin angin Darrieus tiga sudu maupun turbin angin Darrieus empat sudu, akan tetapi fenomena-fenomena ini tidak terlalu besar pengaruhnya terhadap kenaikan nilai gaya lift, torsi dan koefisien daya pada masing-masing sudu maupun turbin angin secara keseluruhan. Hal ini disebabkan karena angin yang tiba di daerah downstream telah kehilangan kecepatannya karena sebelumnya telah mengenai sudu-sudu di daerah upstream.

Walaupun putaran turbin terhambat oleh sudu-sudu di daerah downstream tetapi turbin angin Darrieus ini (baik tiga sudu maupun empat sudu) tetap mampu berputar dengan stabil karena dibantu oleh sudu-sudu daerah upstream yang memiliki nilai kecepatan, gaya lift dan torsi yang cukup tinggi sehingga mampu mengimbangi kekurangan pada daerah downstream.
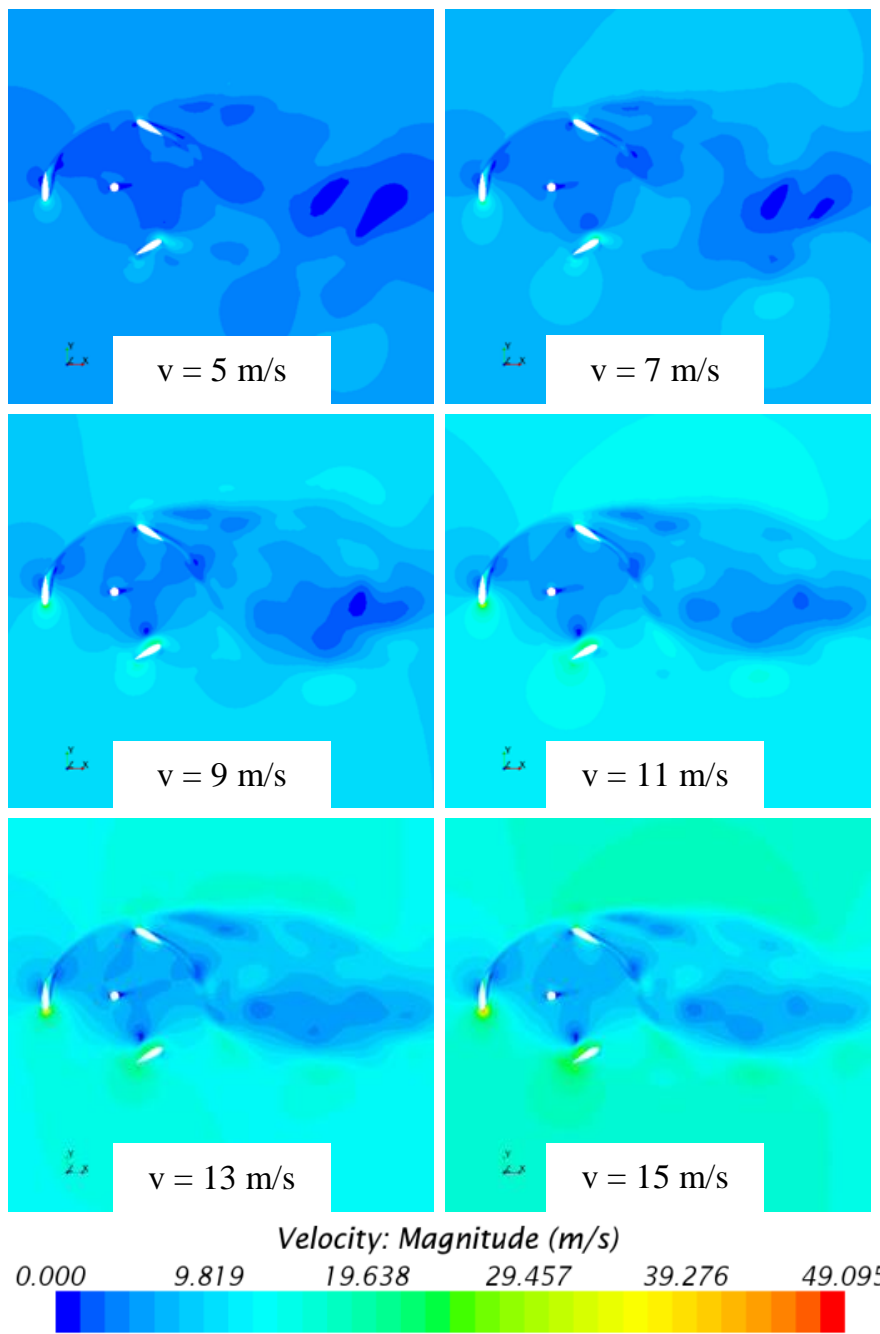

Gambar. 6. Kontur kecepatan turbin angin Darrieus tiga sudu pada sudut putar $90^{\circ}$ dengan variasi kecepatan freestream. 

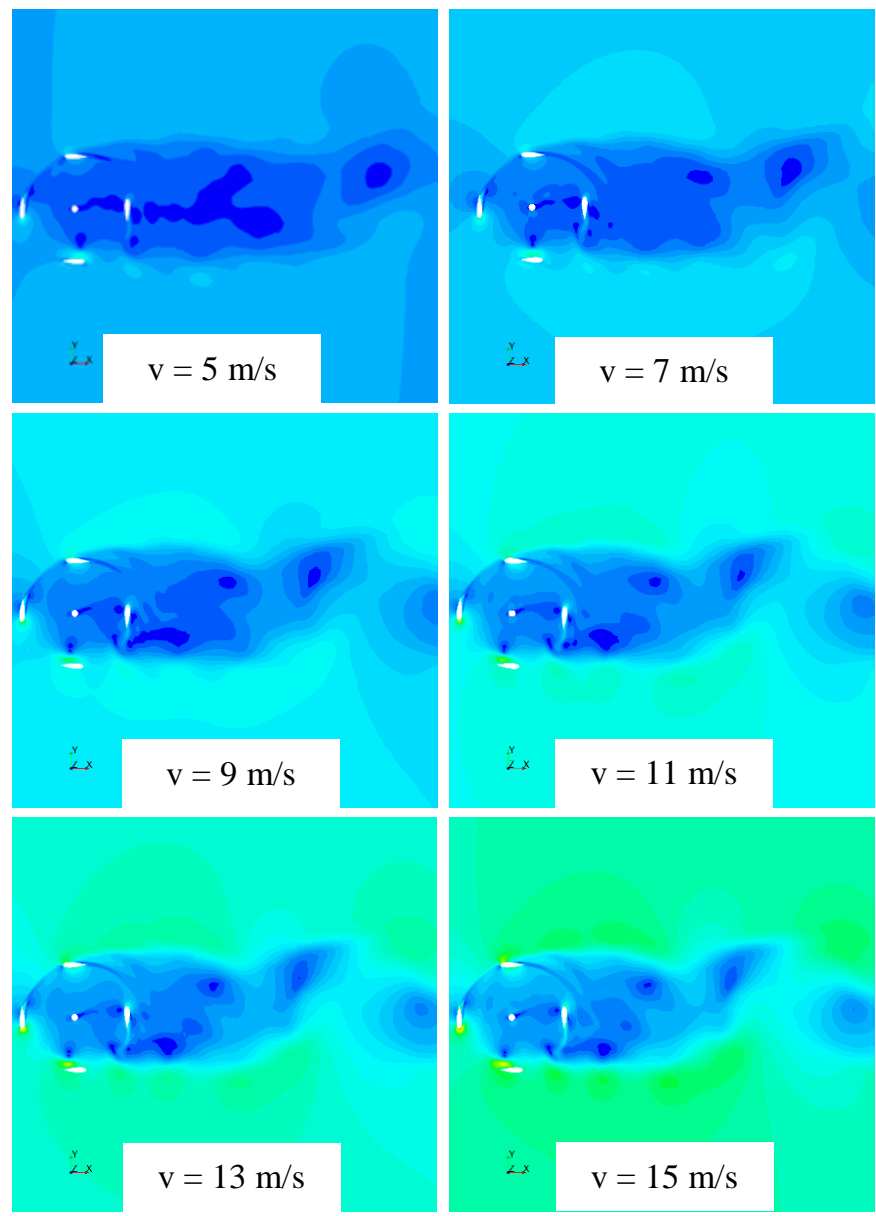

Velocity: Magnitude $(\mathrm{m} / \mathrm{s})$

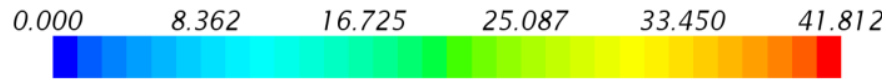

Gambar. 7. Kontur kecepatan turbin angin Darrieus empat sudu pada sudut putar $0^{\circ}$ dengan variasi kecepatan freestream.

\section{B. Kontur Tekanan}

Gambar 8 menunjukkan kontur tekanan turbin angin Darrieus tiga sudu pada berbagai sudut putar dengan kecepatan angin $15 \mathrm{~m} / \mathrm{s}$. Pada kontur tekanan tersebut terlihat bahwa perbedaan tekanan tertinggi terjadi pada sudu yang tegak lurus terhadap arah aliran angin. Hal ini terjadi dikarenakan sisi terluar sudu yang tegak lurus dengan arah aliran angin mendapatkan tekanan yang besar dari angin yang melaluinya sedangkan sisi terdalam sudu tidak dikenai angin secara langsung yang mengakibatkan tekanan nya rendah. Fenomena ini menyebabkan terjadinya gaya lift yang lebih tinggi dari posisi sudu lainnya. Sedangkan pada sudu lainnya tidak memiliki perbedaan tekanan yang terlalu besar karena dipengaruhi oleh vortex dan posisi sudu tersebut berada.

Kontur tekanan turbin angin Darrieus empat sudu ditampilkan pada gambar 9. Pada gambar kontur tekanan tersebut terlihat fenomena yang tidak jauh berbeda dengan turbin tiga sudu, yaitu perbedaan tekanan tertinggi terjadi pada sudu yang tegak lurus terhadap arah aliran angin.

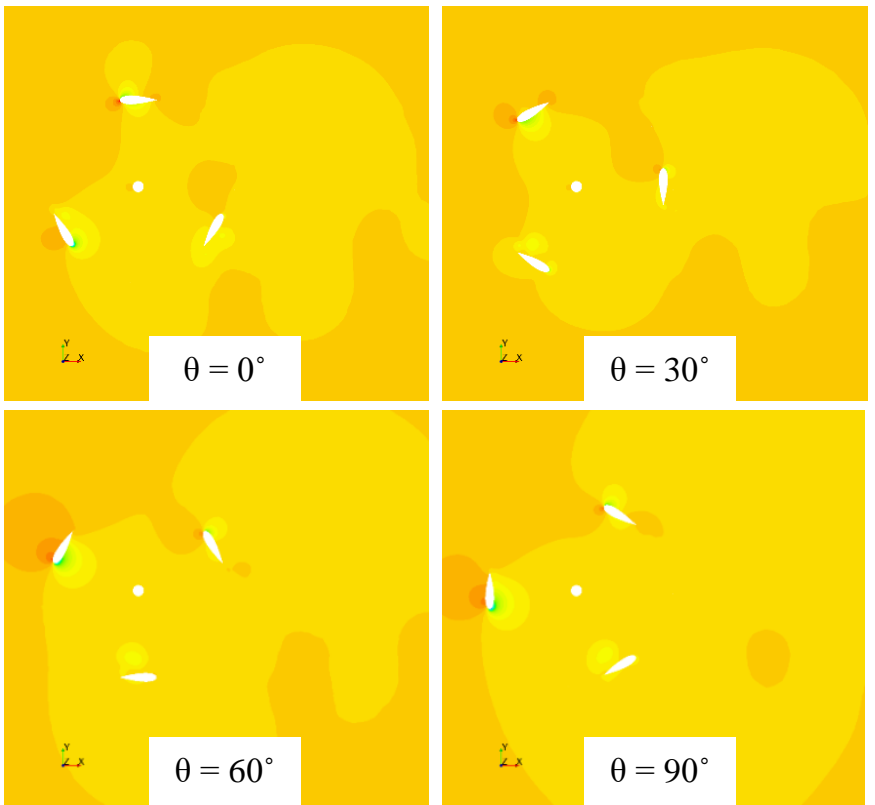

\section{Presstire $(\mathrm{Pa})$}

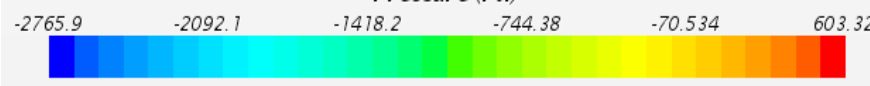

Gambar. 8. Kontur tekanan turbin angin Darrieus tiga sudu pada berbagai sudut dengan kecepatan angin $15 \mathrm{~m} / \mathrm{s}$.

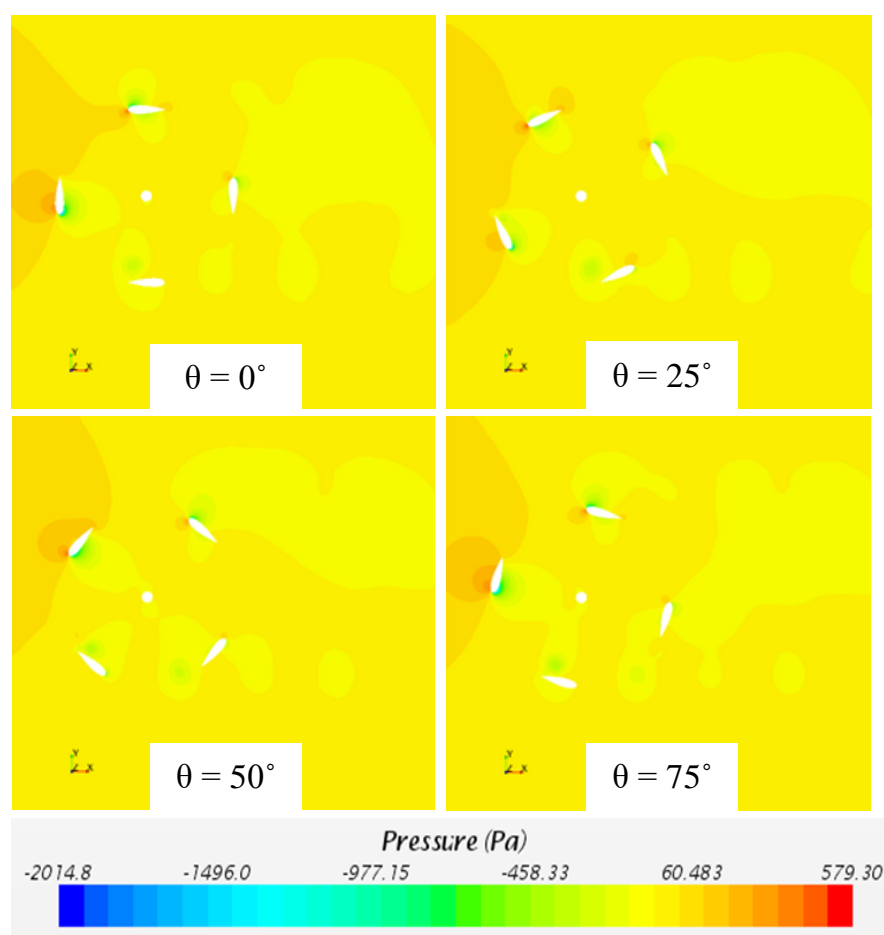

Gambar. 9. Kontur tekanan turbin angin Darrieus empat sudu pada berbagai sudut dengan kecepatan angin $15 \mathrm{~m} / \mathrm{s}$.

\section{Torsi}

Gambar 10.(a) dan 11.(a) menunjukkan torsi yang terjadi pada masing-masing sudu turbin tiga sudu dan empat sudu. Nilai torsi tertinggi tercapai saat suatu sudu tegak lurus dengan arah aliran angin pada sudut putar tertentu, sedangkan sudu lainnya bernilai rendah karena berada di daerah downstream. Hal ini menunjukkan bahwa turbin tetap mampu berputar dan 
menghasilkan torsi total dengan nilai yang baik seperti pada gambar 10.(b) dan 11.(b) dikarenakan salah satu sudu bernilai torsi tinggi, meskipun torsi sudu lainnya bernilai rendah.

Turbin angin membentuk sebuah siklus kenaikan nilai torsi total saat berputar pada nilai kelipatan $120^{\circ}$ untuk turbin tiga sudu dan $90^{\circ}$ untuk turbin empat sudu, dimulai setelah turbin angin melalui putaran $90^{\circ}$. Nilai torsi total semakin tinggi seiring bertambahnya kecepatan angin, dan nilai torsi total maksimal turbin tiga sudu lebih besar daripada turbin empat sudu, akan tetapi profil grafik torsi total turbin empat sudu lebih stabil. Hal ini terjadi karena semakin banyak sudu yang digunakan pada turbin angin Darrieus ini, maka semakin banyak pula sudu "penghambat" dengan nilai torsi kecil atau minus yang akan mengurangi kinerja turbin angin.

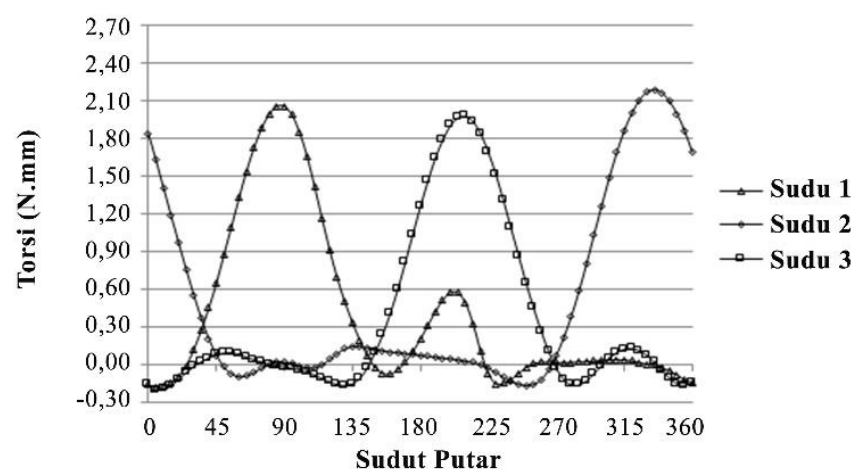

(a)

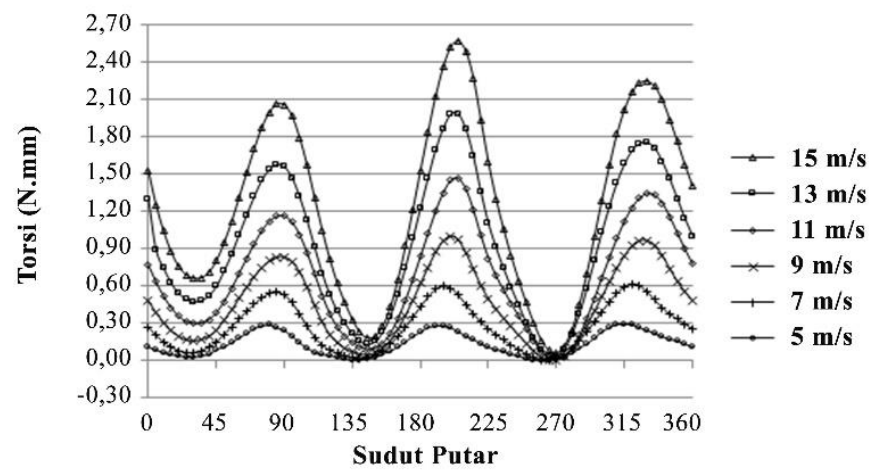

(b)

Gambar. 10. Grafik torsi pada turbin angin tiga sudu. (a) Grafik torsi terhadap sudut putar sudu 1, 2, 3 pada kecepatan freestream $15 \mathrm{~m} / \mathrm{s}$, (b) Grafik torsi total terhadap sudut putar dengan variasi kecepatan freestream.

\section{Koefisien Daya}

Gambar 12 menunjukkan hubungan antara koefisien daya terhadap TSR pada turbin angin Darrieus tiga sudu dan empat sudu. Koefisien daya turbin angin Darrieus tiga sudu dan empat sudu mencapai nilai tertinggi pada 0,4366 dan 0,3766 pada TSR 1,28.Pada rentang TSR 1,08 - 1,28 turbin angin Darrieus tiga sudu memiliki nilai koefisien daya yang lebih tinggi daripada turbin angin Darrieus empat sudu dikarenakan semakin banyak sudu yang digunakan pada turbin angin maka semakin banyak pula sudu yang berada pada daerah downstream yang menghasilkan gaya drag tambahan sehingga nilai torsi yang dihasilkan sangat kecil bahkan bernilai minus dan hal ini berpengaruh pula terhadap koefisien daya yang dihasilkan.

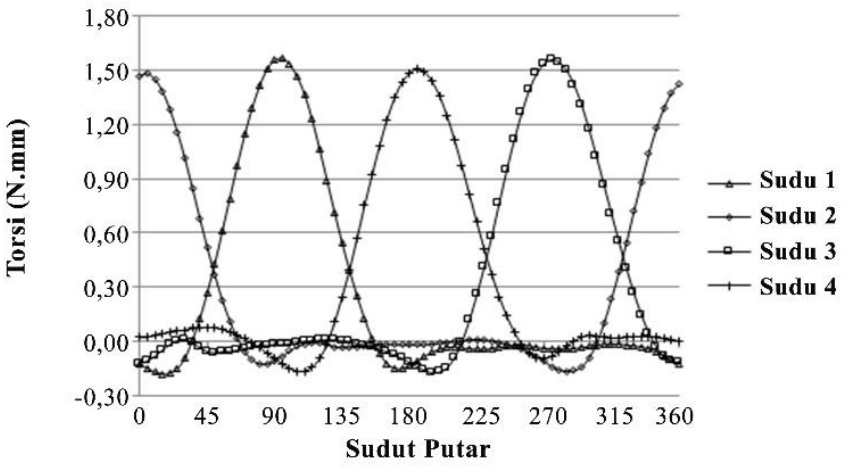

(a)

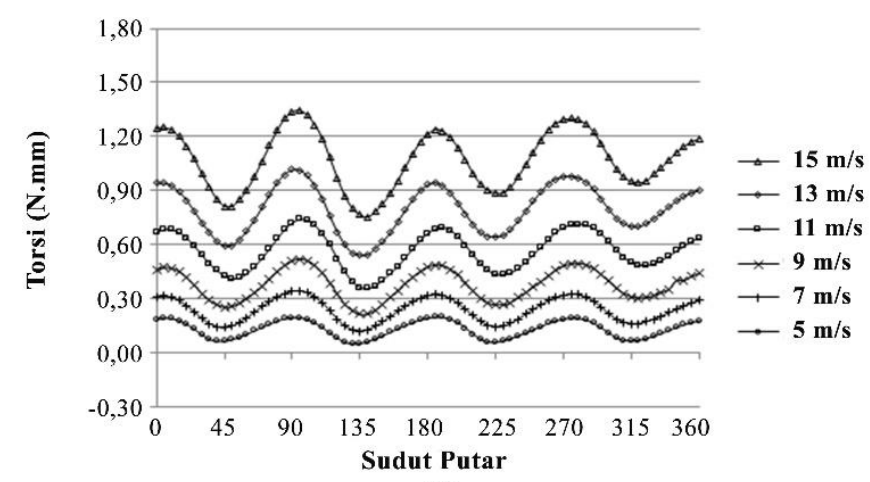

(b)

Gambar. 11. Grafik torsi pada turbin angin empat sudu. (a) Grafik torsi terhadap sudut putar sudu 1, 2, 3, 4 pada kecepatan freestream $15 \mathrm{~m} / \mathrm{s}$, (b) Grafik torsi total terhadap sudut putar dengan variasi kecepatan freestream.

Semakin besar nilai TSR, maka nilai koefisien daya pun akan semakin meningkat hingga nilai TSR tertentu, hingga akhirnya nilainya menurun meskipun TSR terus meningkat. Pada penelitian kali ini tidak tampak adanya penurunan koefisien daya pada nilai TSR tertentu dikarenakan rentang nilai TSR yang digunakan pada penelitian ini relatif kecil sehingga kurang mampu menangkap fenomena penurunan koefisien daya yang terjadi pada turbin angin dengan karakteristik tertentu.

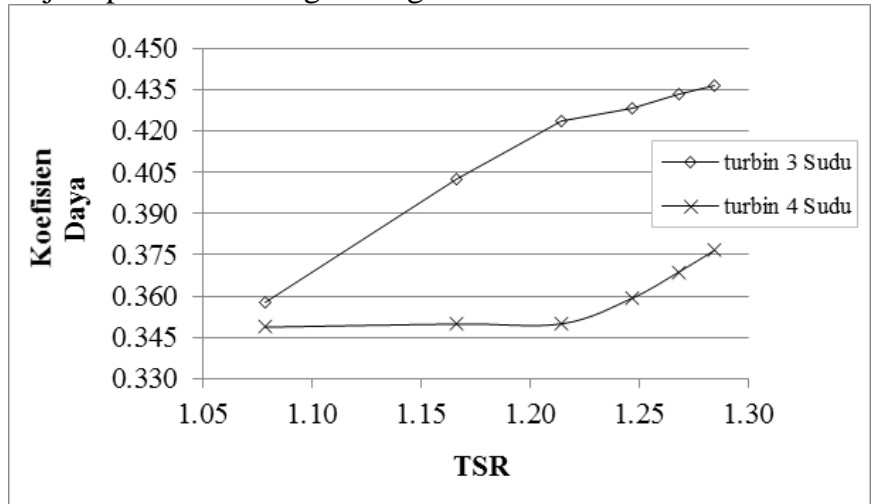

Gambar. 12. Grafik koefisien daya terhadap TSR turbin angin Darrieus tiga sudu dan empat sudu.

\section{KESIMPULAN}

Pada simulasi turbin angin Darrieus dengan variasi jumlah sudu (3 \& 4 sudu) dan kecepatan angin 5, 7, 9, 11, 13 dan 15 $\mathrm{m} / \mathrm{s}$ dapat diambil kesimpulan bahwa:

1) Semakin tinggi kecepatan angin, maka semakin tinggi pula torsi yang dihasilkan. Akan tetapi semakin banyak jumlah 
sudu yang digunakan, maka nilai torsi yang dihasilkan semakin rendah.

2) Semakin tinggi perbedaan tekanan yang terjadi pada suatu sudu, maka semakin besar pula gaya lift yang dihasilkan oleh sudu tersebut dan nilai resultan dari gaya lift dan gaya drag akan bertambah. Pertambahan nilai Resultan gaya ini berbanding lurus dengan pertambahan nilai torsi.

3) Semakin besar gaya lift yang dihasilkan pada suatu sudu, maka semakin tinggi pula kecepatan pada sudu tersebut.

4) Torsi yang dihasilkan oleh sudu-sudu pada daerah upstream lebih tinggi daripada torsi yang dihasilkan pada daerah downstream.

5) Koefisien daya yang dihasilkan berbanding lurus dengan nilai torsi yang terjadi.

6) Kontur aliran dan tekanan serta nilai torsi dan koefisien daya yang dihasilkan oleh turbin angin dipengaruhi oleh jumlah cell dan tipe mesh yang digunakan.

\section{DAFTAR PUSTAKA}

[1] Gorle, J.M.R., L. Chatellier, F. Pons \& M. Ba. 2016. "Flow and performance analyis of H-Darrieus hydroturbine in a confined flow: A computational and experimental study". Journal of Fluids and Structures $66,382-402$.

[2] Hassan, Islam M., Ahmad M. Ali, Mahdi S. Al-Ajmi \& Taher G. Abu ElYazied. 2015. "Effect of Number of Blades and Blade Chord Length on the Performance of Darrieus Wind Turbine". American Journal of Mechanical Engineering and Automation 2, 1:16-25.

[3] Dwiyantoro, B.A., Vivien Suphandani \& Rahman. 2015. "Penelitian Eksperimental tentang Karakteristik Turbin Angin Sumbu Vertikal Jenis Darrieus-Savonius". Seminar Nasional Tahunan Teknik Mesin XIV (SNTTM XIV).

[4] Brusca, S., R. Lanzafame \& M. Messina. 2014. "Design of a vertical-axis wind turbine: how the aspect ratio affects the turbine's performance". International Journal of Energy and Environmental Engineering, 5:333 340 . 